\title{
Preschool/Pre-Kindergarten Education Promoting Student Performance in Later Years: A Qualitative Perspective
}

\author{
Carla J. Thompson ${ }^{1}$ Giang-Nguyen Thi Nguyen ${ }^{2}$ \\ ${ }^{1,2}$ University of West Florida, USA
}

\begin{abstract}
A thoughtful decision confronting parents considering pre-kindergarten or pre-school programs across the United States provided from the literature has focused on school readiness of children within the pre-kindergarten years. Prior to children moving into kindergarten, parents are often concerned with the related potential for increased student achievement and student performance of these children in later years. Public opinion concerning the "worth" of preschool education as a readiness provider for preparing children to enter kindergarten adequately prepared for learning has been a topic of dissention among educators and parents for more than a decade. This qualitative study involved conducting structured interviews with five educators (two pre-school teachers, two kindergarten teachers, and one early learning district administrator) from the same school district located in the southeast region of the United States. The current qualitative study focused on eight specific interview questions generated from the literature review. Each of the eight interview question responses was examined relative to specific criteria, positioning, and information aligned from the related literature. Resulting literature analyses and discussions provide specific viewpoints from the interviews of the five educators regarding the merits and potential worth of early education experiences. Implications of the study findings involve describing potential future research efforts aimed at examining influences of early education or preschool experiences related to students performance levels and attitudes relative to later school achievement.
\end{abstract}

Keywords: Preschool education, Qualitative Research, Kindergarten

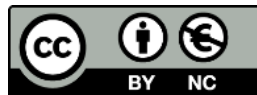

This is an open access article under the CC-BY-NC license

\section{INTRODUCTION}

Influences of preschool education on child development and the potential for preschool education to provide lasting effects on children as evidenced by early education research findings provide the major motivation for this study (Barnett, 2008; Learning Policy Institute 2021). Also emphasized in the literature is the lasting effects of early learning programs involving children from the 1960s and 1970s who attended preschool programs have demonstrated lasting benefits into adulthood as compared with children who did not attend preschool (Learning Policy Institute, 2021). Examining specific characteristics and issues focused on preschool education programs and the potential influence on children for later learning provided the impetus for the current study. Literature indicating that early education may improve the performance of children in later grades in school has been documented in current research efforts (Learning Policy Institute, 2021). The current study moves the research findings forward toward examining specific qualities or characteristics of preschool education environments that might assist in improving the performance of children in later years even though research contradicting these findings may also 
exist. The current study sought to explore potential merits of pre-school education relative to driving students in later school considerations. Current practices for families to begin placing their children in early learning schools are leading the way toward more common practices.

The objectives of this qualitative research study include: (1) reviewing pertinent literature aimed at more than 50 years of kindergarten and Pre-K programs; (2) conducting extensive interviews of five pre- $\mathrm{K}$ and Kindergarten educators to discern perspectives of professional educators regarding the role of Pre-K programs in preparing children for educational prowess in later years in school.; and (3) identifying limitations of previous research, exploring current strides in Pre-K education, and positing options for educators and parents for predicting success of children in later grades.

\section{LITERATURE REVIEW}

The importance of Preschool on future learning in children and adults was captured in a study conducted by the Excel P-3 Project, a collaborative project between Boston Public Schools (USA), the University of Michigan, and the Harvard Graduate School (USA) to discern specific benefits of early childhood education (preschool) on students at later ages (McCormick, Hsueh, Weiland, \& Bangser, 2017) This longitudinal study is focused on assessing if skills attained in preschool are sustained through third grade. Studies focused on assessing the impact or influence of preschool education on learner performance in later years have emphasized specific assessments and follow-up periodic testing of students rather than specific information gleaned from veteran preschool and early learning educators' perceptions and observations. The current study focuses on specific information and observations of preschool educators whose careers are vested in working with parents and preschoolers focused on moving forward in their academic and physical development. Previous studies focused on long-term effects of preschool education emphasize the use of test scores as measures of sustainability and achievement. The current study focuses on preschool teachers and leaders who have extensive experience in working with preschool students, parents, and community leaders. The current study participants are experienced early childhood educators and leaders focused on working with both preschool and elementary students. The current study emphasizes the perceptions and feedback of these early education professionals as key partners for discerning the skills development transpiring within preschool students, specific Influences of parents, and hands-on experiences with preschool and elementary grade students. Previous studies focused on examining testing trends from preschoolers to third grade performances; whereas, the current study emphasized the direct observations of preschool teachers within the framework of theory and practice. The data retrieved by the current study stem from directly addressing teachers within interview settings and the alignment of the teacher interview data to sound theory and practice elements. The current study establishes a strong grounded baseline for future research associated with early learning sustainability and predictability in terms of early learning content and sustainability focused research efforts

The theoretical interpretive framework for the current study is framed within social constructivism. The "lived experiences and interactions with others...are shaped by individual experiences with individual values honored...and are negotiated among individuals." (Creswell \& 
Poth, 2018, p. 35). The premise behind social constructivism is interpretivism (Denzin \& Lincoln, 2011) or individuals seeking to determine specific viewpoints of lived experiences. Interpretivism was a key element in shaping the background for designing the qualitative methodology pertinent to the overriding research question, "What are the relationship between students' Pre-K school participation and students' performance or achievement in later years as perceived by key educators?"

\section{RESEARCH METHOD}

Using the foundational constructs of Social Constructivism, the researchers established guidelines for examining multiple realities shaped by individual experiences, observations, and interactions with others to determine specific values shared and honored among individuals (Creswell \& Poth, 2018). The qualitative methodology selected for examining the major research question was interviewing with analyses derived from an historical and social constructivist perspective. Ethical considerations associated with conducting interviews and aligned qualitative research methods were examined specifically for conducting the data collection, analyses, and reporting, (Seiber \& Tolich, 2013). Dissemination of results were also carefully examined for ethical considerations specific to pertinent audiences and for publication purposes (Seiber \& Tolich, 2013).

Specific research methods utilized for the study included interviews from five educators (two pre-school teachers, two kindergarten teachers, and one district early learning administrator). Each of the five interviewees was provided with the same eight specific interview questions for responses. The following eight interview questions were posited to each of the five interviewees:

(1) Interview Question \#1: What evidence do you personally feel is pertinent to support the need for every child to have the opportunity for formal Pre-K education?

(2) Interview Question \#2: Have you watched children who have attended formal Pre-K programs move forward in reading or other academic areas? Do you feel these children move forward more easily than children who have not had Pre-K formal education? Please explain your answer.

(3) Interview Question \#3: What characteristics of formal Pre-K education programs do you feel are most helpful for children entering kindergarten? First grade?

(4) Interview Question \#4: What characteristics or skills of children are most important for kindergarten, first grade, and beyond for success in school? Do you feel children from Pre-K education programs have developed these skills?

(5) Interview Question \#5: Working at a school where you see your Pre-K students go into kindergarten and beyond, do you feel children in your school district who have attended a Pre-K program are more appropriately prepared for school than children who have not attended a formal Pre-K program?

(6) Interview Question \#6:_Keeping in mind students you see in kindergarten and above at your school, do you know of children who did not attend any type of Pre-K formal education program? Do you feel the children who did not attend Pre-K require more time and learning experiences, less time and 
learning experiences, or the same time and learning experiences as children who completed formal Pre-K programs for moving forward successfully in reading and other academic areas? What is your answer based on?

(7) Interview Question \#7: Describe the importance of Pre-K formal education as per your opinion and/or justified rationale.

(8) Interview Question \#8: Do you tell parents of the importance of Pre-K formal education for later success in school? Please discuss.

Additional information was collected by researchers from current research and texts focused on early learning. The interview responses and textual data collection were analyzed using tenets from social constructivism, i.e., patterns of meaning were generated inductively by the researchers using open-ended questioning of participants and allowing constructivist researchers to "focus on the specific contexts in which people live and work in order to understand the historical and cultural settings of the participants" (Creswell \& Poth, 2018, p. 24). The validity and reliability of the data analyses utilized by researchers included several considerations: (1) Researchers utilized an interviewer who was a former early childhood specialist for the school district and was familiar with the programs and policies of the early learning program within the school district. Interview data retrieved by the interviewer (in-person and/or by phone) were entered into a protected data file.

Study participants included early childhood teachers/administrators who volunteered to participate in the study from a memo sent to them from a former early childhood teacher who was no longer working in the district after her 20-year career with the district. Study volunteers were selected from one medium size suburban/rural county public school district located in the southeast region of the United States with approximately 30,000 students and represented early childhood and/or kindergarten teachers and one early childhood district administrator.

The researchers utilized triangulation to discern the validity and interpretation of the interview data using three approaches: (1) Interview data were examined relative to stated school district policies and practices manuals published by the school district; (2) Interview data were sent back to the respective respondents to assess reliability and reviewed by each respondent for accuracy in reporting; and (3) researchers utilized an external source for compiling and reporting the data from Rubin and Rubin (2005).

\section{FINDINGS AND DISCUSSION}

Each of the eight questions was analyzed using the five qualitative analyses approach posited by Rubin and Rubin (2005): Recognition, Elaboration;

Integration, and Coding, with the discussion of Synthesis following the presentation of information as a summary of the findings. The following eight tables depict the procedures and individual context of each of the five participants' responses and discussions.

Interview Question \#1: What evidence do you personally feel is pertinent to support the need for every child to have the opportunity for formal Pre-K education? 
Table 1: Interpretation of Responses to Q1

\begin{tabular}{|c|c|c|c|}
\hline Recognition & Elaboration & Integration & Coding \\
\hline $\begin{array}{l}\text { Child needs basic } \\
\text { components of } \\
\text { literacy, language, } \\
\text { mathematics, and } \\
\text { social-emotional } \\
\text { skills; } \\
\text { Using pre and } \\
\text { post assessments } \\
\text { from the Pre-K year; } \\
\text { Suggest findings } \\
\text { of Pre-K students out } \\
\text { performing non-Pre- } \\
\text { K students in } \\
\text { subsequent years }\end{array}$ & 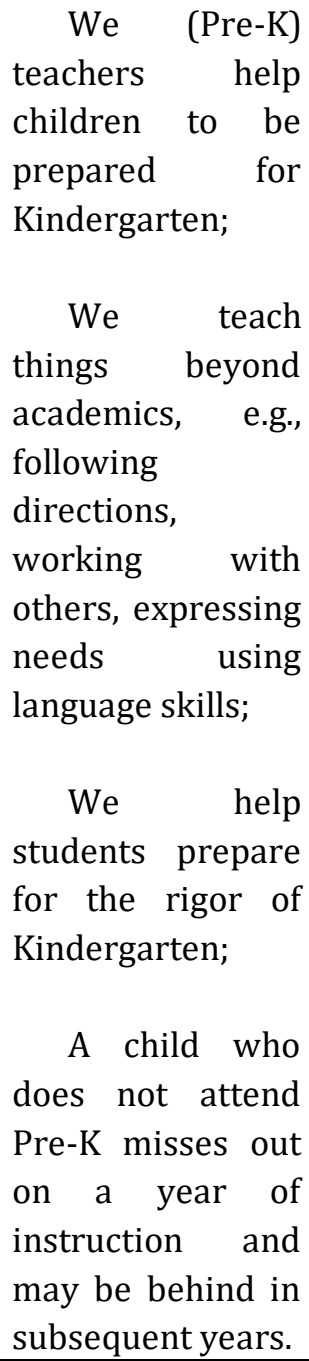 & $\begin{array}{l}\text { Gormley } \\
\text { (2017) }\end{array}$ & $\begin{array}{l}\text { Evidence for } \\
\text { students to have } \\
\text { Pre-K: } \\
\quad \text { components } \\
\text { of literacy, } \\
\text { especially } \\
\text { communications } \\
\text { and language } \\
\text { skills; } \\
\quad \text { Pre-K } \\
\text { evidence should } \\
\text { include } \\
\text { examining } \\
\text { subsequent } \\
\text { years } \\
\quad \text { examining } \\
\text { basal abilities of } \\
\text { child and home } \\
\text { conditions }\end{array}$ \\
\hline
\end{tabular}

Interview Question \#2: Have you watched children who have attended formal Pre-K programs move forward in reading or other academic areas? Do you feel these children move forward more easily than children who have not had Pre-K formal education? Please explain.

Table 2: Interpretation of Responses to Q2

\begin{tabular}{|c|c|c|c|}
\hline & Elaboration & Int & \\
\hline $\begin{array}{l}\text { Managing the } \\
\text { state of Florida VPK } \\
\text { assessment data for } \\
10 \text { years indicates a } \\
\text { high percentage of } \\
\text { children enter VPK }\end{array}$ & \begin{tabular}{l}
\multicolumn{1}{c}{ My Pre-K } \\
students have a \\
broad baseline \\
for scaffolding \\
their future \\
learning;
\end{tabular} & $\begin{array}{l}\quad \text { Center for } \\
\text { Public } \\
\text { Education } \\
\end{array}$ & $\begin{array}{l}\quad \text { Support for } \\
\text { Pre-K impact in } \\
\text { later years: } \\
\quad \text { Entering } \\
\text { school with low } \\
\text { skills }\end{array}$ \\
\hline
\end{tabular}




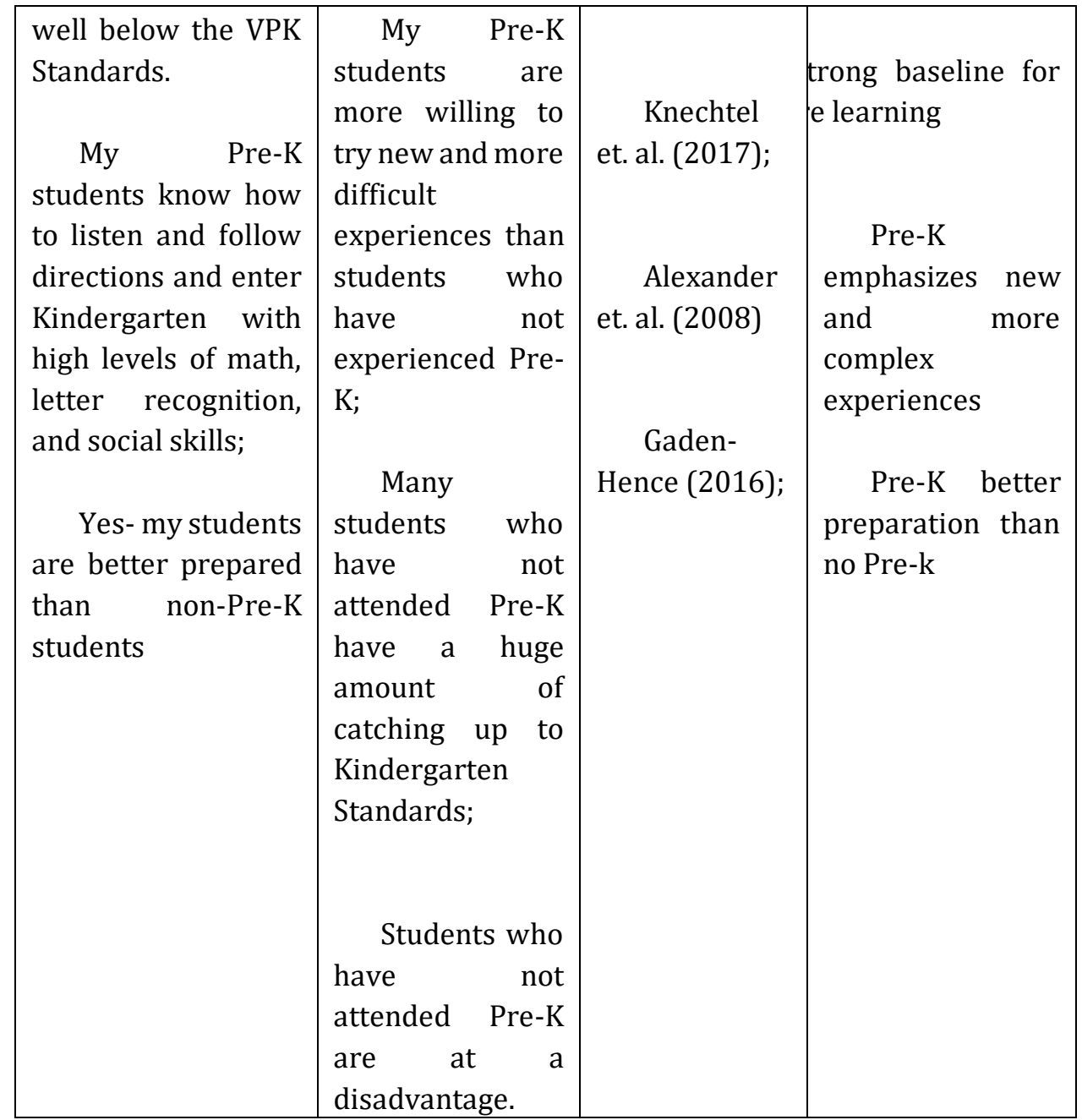

Interview Question \#3: What characteristics of formal Pre-K education programs do you feel are most helpful for children entering kindergarten? First Grade?

Table 3: Interpretation of Responses to Q3

\begin{tabular}{|c|c|c|c|}
\hline Recognition & Elaboration & Integration & Coding (\#) \\
\hline \multirow{4}{*}{$\begin{array}{l}\text { Organized play } \\
\text { within a structured } \\
\text { environment. }\end{array}$} & \multirow{4}{*}{$\begin{array}{l}\text { Pre-K setting } \\
\text { is the building block } \\
\text { for critical social and } \\
\text { emotional needs; }\end{array}$} & \multirow{6}{*}{$\begin{array}{l}\text { Alexander } \\
\text { et. al. (2017) }\end{array}$} & $\underline{\text { Key }}$ \\
\hline & & & characteristics of \\
\hline & & & Pre-K programs: \\
\hline & & & Appropriate \\
\hline \multirow{4}{*}{$\begin{array}{l}\text { Reading books } \\
\text { and working with open } \\
\text { ended questions. }\end{array}$} & & & curriculum with \\
\hline & Activities & & focus \\
\hline & requiring students & & preparation for \\
\hline & $\begin{array}{l}\text { to think and ponder } \\
\text { questions; }\end{array}$ & $\begin{array}{l}\text { Fitzpatrick } \\
\text { (2008) and }\end{array}$ & \\
\hline
\end{tabular}




\begin{tabular}{|c|c|c|c|}
\hline $\begin{array}{l}\text { Communicating } \\
\text { in full sentences and } \\
\text { thoughts; }\end{array}$ & $\begin{array}{l}\text { Well-rounded } \\
\text { and } \quad \text { expanded } \\
\text { curriculum; }\end{array}$ & $\begin{array}{l}\text { Knechtel et. al. } \\
\text { (2017); }\end{array}$ & $\begin{array}{l}\quad \text { Strong } \\
\text { baseline for future } \\
\text { learning }\end{array}$ \\
\hline $\begin{array}{l}\text { All aspects of } \\
\text { literacy, mathematics, } \\
\text { science, and social } \\
\text { skills and } \\
\text { small class sizes; }\end{array}$ & $\begin{array}{l}\text { Strong } \\
\text { connection to } \\
\text { families; } \\
\text { Activities for } \\
\text { exposing students to } \\
\text { preparation for the } \\
\text { Standards }\end{array}$ & $\begin{array}{l}\text { Gaden- } \\
\text { Hence (2016); } \\
\text { Gaden- } \\
\text { Hence (2016); }\end{array}$ & $\begin{array}{l}\text { Pre-K } \\
\text { emphasizes prep } \\
\text { for Standards } \\
\text { Pre-K better } \\
\text { preparation than } \\
\text { no Pre-k }\end{array}$ \\
\hline
\end{tabular}

Interview Question \#4:_What characteristics or skills of children are most important for kindergarten, first grade, and beyond for success in school? Do you feel children from Pre-k education programs have developed these skills?

Table 4: Interpretation of Responses to Q4

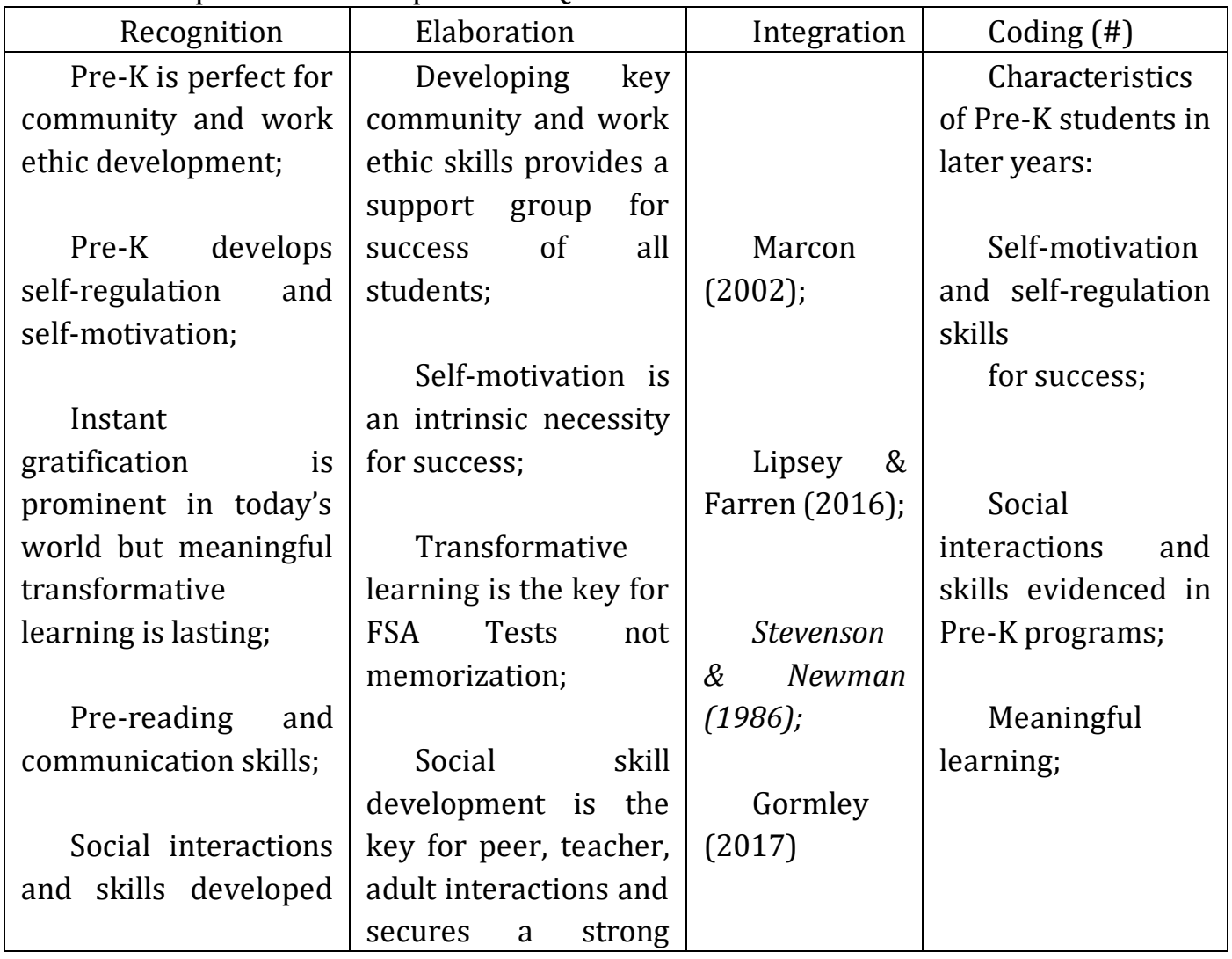




\begin{tabular}{|l|l|l|l|}
\hline $\begin{array}{l}\text { successfully through } \\
\text { the VPK program }\end{array}$ & $\begin{array}{l}\text { successful academic } \\
\text { life }\end{array}$ & $\begin{array}{l}\text { Pre-reading and } \\
\text { communication } \\
\text { skills; }\end{array}$ \\
\hline
\end{tabular}

Interview Question \#5: Working at a school where you see your Pre-K students go into kindergarten and beyond, do you feel children in Escambia County School District who have attended a formal Pre-K program are more appropriately prepared for school than children who have not attended a formal Pre-K program?

Table 5: Interpretation of Responses to Q5

\begin{tabular}{|c|c|c|c|}
\hline Recognition & Elaboration & Integration & Coding (\#) \\
\hline $\begin{array}{l}\text { Yes, absolutely Pre- } \\
\text { K students are } \\
\text { more prepared for } \\
\text { entering } \\
\text { kindergarten than } \\
\text { students who have } \\
\text { not experienced } \\
\text { Pre-K; } \\
\text { This question } \\
\text { needs strong } \\
\text { examination by } \\
\text { school } \\
\text { administrators. } \\
\text { Yes, Pre-K students } \\
\text { have more } \\
\text { academic and social } \\
\text { skills than non-Pre- } \\
\text { K students to be } \\
\text { successful in } \\
\text { Kindergarten and } \\
\text { beyond }\end{array}$ & $\begin{array}{l}\text { Teachers in later } \\
\text { grades who have } \\
\text { had my children } \\
\text { from Pre-K tell me } \\
\text { how well they } \\
\text { perform and how } \\
\text { many more social } \\
\text { and academic skills } \\
\text { my former children } \\
\text { demonstrate than } \\
\text { children who did } \\
\text { not attend a Pre-K } \\
\text { program. } \\
\text { Administrators and } \\
\text { school officials need } \\
\text { to examine the } \\
\text { successes of Pre-K } \\
\text { in subsequent years. }\end{array}$ & $\begin{array}{l}\text { Lipsey \& Farren } \\
\qquad \text { (2016); } \\
\text { Gormley (2017) }\end{array}$ & $\begin{array}{c}\text { Preparation of } \\
\text { Pre-K student vs } \\
\text { non-Pre-K } \\
\text { student for } \\
\text { entering school: } \\
\text { Support from all } \\
\text { interviewees on } \\
\text { Pre-K higher } \\
\text { than non-Pre-K } \\
\text { Social } \\
\text { interaction and } \\
\text { skills evidenced } \\
\text { in Pre-K } \\
\text { programs; } \\
\text { Pre-reading and } \\
\text { communication } \\
\text { skills; }\end{array}$ \\
\hline
\end{tabular}

Interview Question \#6: Keeping in mind students you see in kindergarten and above at your school, do you know of children who did not attend any type of Pre-K formal education program? Do you feel the children who did not attend Pre-K require more time and learning experiences, less time and learning experiences, or the same time and learning experiences as children who completed formal Pre-K programs for moving forward successfully in reading and other academic areas? Justify your answer. 
International Journal of Emerging Issues in Early Childhood Education (IJEIECE), Vol. 3 (1), Page: 44-58

Preschool/Pre-Kindergarten Education Promoting Student Performance in Later Years: A Qualitative Perspective

Carla J. Thompson, Giang-Nguyen Thi Nguyen

Table 6: Interpretation of Responses to Q6

\begin{tabular}{|c|c|c|c|}
\hline Recognition & Elaboration & Integration & Coding (\#) \\
\hline $\begin{array}{l}\text { This question needs } \\
\text { strong attention of } \\
\text { school administrators. } \\
\text { Yes, formal Pre-K } \\
\text { students have higher } \\
\text { academic and social } \\
\text { skills than non-Pre-K } \\
\text { students based on my } \\
\text { observations } \\
\text { Yes, students with no } \\
\text { formal Pre-K start } \\
\text { lower than students } \\
\text { with formal Pre-K } \\
\text { based on Florida } \\
\text { Readiness Screened } \\
\text { (FRS)scores }\end{array}$ & 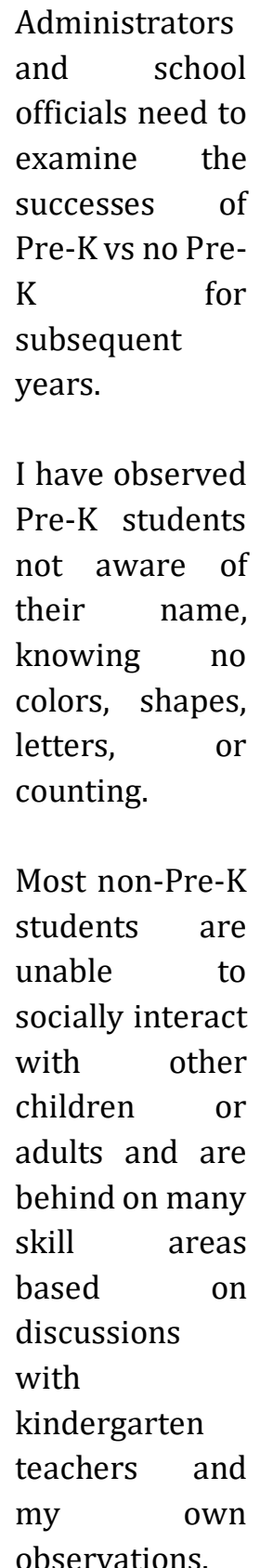 & $\begin{array}{l}\text { Lipsey \& } \\
\text { Farren } \\
(2016) ; \\
\text { Gormley } \\
(2017) \\
\text { Clements et. } \\
\text { al. (2017) }\end{array}$ & 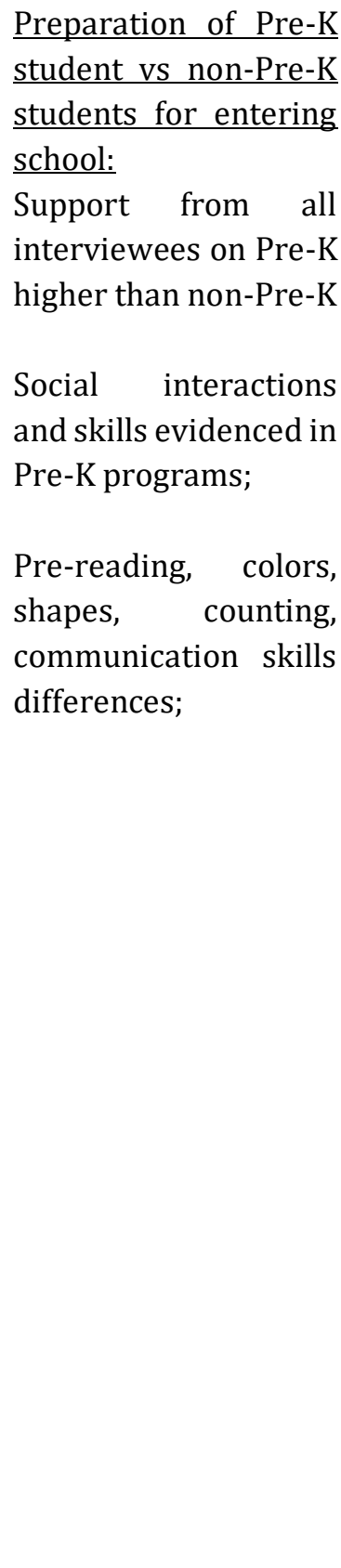 \\
\hline
\end{tabular}

Interview Question \#7: Describe the importance of Pre-K education as per your opinion and justify. 
Table 7: Interpretation of Responses to Q7

\begin{tabular}{|c|c|c|c|}
\hline Recognition & Elaboration & Integration & Coding (\#) \\
\hline $\begin{array}{l}\text { Passionate about } \\
\text { the need for formal } \\
\text { Pre-K for all } \\
\text { students justified } \\
\text { by the generational } \\
\text { poverty within } \\
\text { Escambia County } \\
\text { schools. } \\
\text { The topics covered } \\
\text { now in schools are } \\
\text { much higher than } \\
25 \text { years ago with } \\
\text { Kindergarten } \\
\text { equaling first grade } \\
\text { topics and Pre-K } \\
\text { focusing on } \\
\text { Kindergarten. } \\
\text { Pre-K sets the stage } \\
\text { for success in } \\
\text { school. } \\
\text { All Pre-K students } \\
\text { are more prepared } \\
\text { for kindergarten } \\
\text { and beyond than } \\
\text { students with no } \\
\text { Pre-K experience. }\end{array}$ & $\begin{array}{l}\text { The generational } \\
\text { poverty in } \\
\text { Escambia County is } \\
\text { deep and Pre-K will } \\
\text { provide the jump } \\
\text { start for students } \\
\text { and families in } \\
\text { poverty. } \\
\text { Community has a } \\
\text { responsibility to } \\
\text { provide Pre-K } \\
\text { opportunities for } \\
\text { all children to } \\
\text { begin their } \\
\text { educational lives } \\
\text { The lack of Pre-K } \\
\text { for all is a } \\
\text { disservice for } \\
\text { children } \\
\text { Pre-K students } \\
\text { begin school at an } \\
\text { advantage socially } \\
\text { and academically } \\
\text { with the skills } \\
\text { necessary for } \\
\text { learning standards }\end{array}$ & $\begin{array}{l}\text { Stevenson \& } \\
\text { Newman } \\
\text { (1986); } \\
\text { Fitzpatrick } \\
\text { (2008); } \\
\text { Center for } \\
\text { Education } \\
\text { (2008); } \\
\text { Pianta et.al. } \\
\text { (2008) }\end{array}$ & $\begin{array}{l}\text { Importance of Pre-K } \\
\text { from Pre-K Staff: } \\
\text { Support from all } \\
\text { interviewees on Pre- } \\
\text { K higher than non- } \\
\text { Pre-K } \\
\text { (4) } \\
\text { Social interactions } \\
\text { and skills evidenced } \\
\text { in Pre-K programs; } \\
\text { Pre-reading, colors, } \\
\text { shapes, counting, } \\
\text { communication } \\
\text { skills } \\
\text { Generational } \\
\text { poverty concerns } \\
\text { and the need for } \\
\text { educating families } \\
\text { and communities }\end{array}$ \\
\hline
\end{tabular}

Interview Question \#8: Do you tell parents of the importance of Pre-K formal education for later success in school? Please discuss.

Table 8: Interpretation of Responses to Q8

\begin{tabular}{|c|c|c|c|}
\hline Recognition & Elaboration & Integration & Coding (\#) \\
\hline $\begin{array}{l}\text { Yes, I am involved } \\
\text { with Every Child a } \\
\text { Reader in Escambia } \\
\text { where reading pals } \\
\text { spend } 45 \text { minutes to } \\
\text { an hour with a child }\end{array}$ & $\begin{array}{l}\text { Pre-K programs are } \\
\text { a very important } \\
\text { connection to our } \\
\text { parents } \\
\text { children in the } \\
\text { community who } \\
\text { may not have a }\end{array}$ & $\begin{array}{l}\text { Clements et. al. } \\
\text { (2017) }\end{array}$ & $\begin{array}{l}\text { Importance of Pre- } \\
\text { K for Parents: } \\
\text { Support from all } \\
\text { interviewees on } \\
\text { Pre-K higher than } \\
\text { non-Pre-K }\end{array}$ \\
\hline
\end{tabular}




\begin{tabular}{|l|l|l|l|}
\hline $\begin{array}{l}\text { weekly and visit with } \\
\text { parents. }\end{array}$ & $\begin{array}{l}\text { connection in their } \\
\text { home. }\end{array}$ & $\begin{array}{l}\text { Social interactions } \\
\text { evidenced in } \\
\text { formal Pre-K } \\
\text { programs; }\end{array}$ \\
$\begin{array}{l}\text { Yes, I encourage } \\
\text { every parent I meet } \\
\text { to enroll their } \\
\text { children in Pre-K and } \\
\text { taught are not } \\
\text { independence at } \\
\text { home with the } \\
\text { available } \\
\text { importance of early } \\
\text { lechnologies and arning, especially } \\
\text { in reading. }\end{array}$ & $\begin{array}{l}\text { Newman } \\
\text { (1986); } \\
\text { working parents. } \\
\text { Fitzpatrick } \\
\text { (2008); } \\
\text { Gaden-Hence } \\
(2016)\end{array}$ & $\begin{array}{l}\text { Fostering learning } \\
\text { with } \\
\text { community/family } \\
\text { support for Pre-K }\end{array}$ \\
$\begin{array}{l}\text { Yes, it is amazing } \\
\text { how much a four- or } \\
\text { five-year-old can } \\
\text { learn in a short time } \\
\text { period. }\end{array}$ & $\begin{array}{l}\text { Pre-K fosters } \\
\text { creativity, thinking, } \\
\text { and thirst for } \\
\text { knowledge. }\end{array}$ & \\
\hline
\end{tabular}

\section{RESULTS}

The following results emerged from the syntheses of the qualitative analyses performed on the eight interview questions posited to five interviewees. The synthesis statement with literature justification depicts the results from the qualitative interviews:

Synthesis statements:

(a) Interviewees discussed several types of evidence for the need for Pre-K programs for all students also supported from the literature: (1) evidence supporting the promotion of literacy skills, especially communication and language skills (Gormley, 2017); (2) evidence of the impact of Pre-K on students' outcomes in kindergarten and subsequent years (Knechtel et al., 2017); and (3) use of assessments examining basal abilities of the child and home conditions (Pianta et al., 2009).

(b) Interviewees provided testimony supporting the strong positive impact of Pre-K on students' achievement and performance in later school years emphasizing the following areas of impact also substantiated by the literature:

(1) Pre-K provides a strong baseline for all students' future learning experiences (Knechtel et al., 2017);

(2) Pre-K is essential for children entering school with low skills (Pianta et al., 2009); and

(3) Pre-K emphasizes new and more complex experiences focusing on better preparation for children than no-PreK (Gaden-Hence, 2016)

(4) Pre-K provides a better preparation for the child than no Pre-K (Gaden-Hence, 2016). 
(c) Interviewees provided substantive suggestions based on their experiences of the key characteristics necessary for Pre-K programs also supported by the literature as follows: (1) appropriate curriculum focused on preparation for the Kindergarten Standards (Alexander et. al., 2017; (2) strong baseline for future learning (Fitzpatrick, 2008 and Knechtel et. al. 2017); (3) emphasizes complex experiences (Gaden-Hence, 2016); and (4) Pre-K provides a better preparation for the child than no Pre-K (GadenHence, 2016).

(d) Interviewees submitted their perspectives of the characteristics of Pre-K students they have observed in Kindergarten and in later years also supported by the literature as follows: (1) students possess self-motivation and self-regulation skills for success (Marcon, 2002); (2) students are adept with social interaction skills, especially communication skills (Lipsey \& Farren; 2016 \& Gormley, 2017); and (3) students are able to comprehend meaningful learning on tests and in verbal communications (Stevenson \& Newman, 1986).

(e) Interviewees presented their personal perspectives of comparing the preparedness of Pre- $\mathrm{K}$ students versus the preparedness of non-Pre-K students for entering Kindergarten within their Schools with supportive literature as follows: All interviewees definitively stated Pre-K students enter school in much higher levels of preparedness than preparedness levels of non-Pre-K students, especially in the areas of communication skills, social skills, and pre-reading skills (Gaden-Hence, 2016; Lipsey \& Farren, 2016; and Gormley, 2017).

(f) Interviewees presented their personal perspectives of comparing the preparedness of Pre- $K$ students versus the preparedness of non-Pre-K students for entering Kindergarten in Escambia County Schools with supportive literature as follows: All interviewees definitively stated Pre-K students enter school in much higher levels of preparedness than preparedness levels of non-Pre-K students, especially in the areas of communication skills, social skills, and pre-reading skills (Gaden-Hence, 2016; Lipsey \& Farren, 2016; Gormley, 2017).

(g) Interviewees overwhelmingly agreed that students who start Kindergarten with no formal Pre-K program begin much lower on virtually all skills than students who have attended a formal Pre-K program and this viewpoint if corroborated in the literature (Clements et. al., 2017; Gaden-Hence, 2016; Gormley, 2017; Lipsey \& Farren, 2016).

(h) Interviewees also overwhelming agreed on the strong importance of children attending a formal Pre-K program prior to entering school (Clements et. al., 2017) justifying this importance with the following reasons corroborated by the literature: (1) social interactions skills of Pre-K students are much higher than non-Pre-K students (Lipsey \& Farren, 2016); (2) pre-reading, identification of colors, shapes, counting, and communication skills are much higher than non-Pre-K students (Center for Education, 2007; Center for Education, 2008; Pianta et. al, 2008); and (3) 
generational poverty is a key reason why formal Pre-K must be provided for all students to be allowed the opportunity to enter school (kindergarten) prepared to move forward with peers (Stevenson \& Newman, 1986; Fitzpatrick, 2008; Lipsey \& Farren, 2016).

(i) Interviewees were in complete agreement regarding the importance of discussing the need for formal Pre-K with parents (Clements et. al., 2017) justifying their parent discussions with the following rationale items: (1) social interactions of children in formal Pre-K programs are high functioning and preparing children for advancement in school and at home (Stevenson \& Newman,, 1986; Fitzpatrick, 2008; Gaden-Hence, 2016); and (2) discussing with parents about formal Pre-K attendance for their children fosters learning with community and family support for formal Pre-K programs (Lipsey \& Farren, 2016; Gaden-Hence, 2017).

(d) Interviewees were in complete agreement regarding the importance of discussing the need for formal Pre-K with parents (Clements et. al., 2017) justifying their parent discussions with the following rationale items: (1) social interactions of children in formal Pre-K programs are high functioning and preparing children for advancement in school and at home (Stevenson \& Newman, 1986; Fitzpatrick, 2008; Gaden-Hence, 2016); and (2) discussing with parents about formal Pre-K attendance for their children fosters learning with community and family support for formal Pre-K programs (Lipsey \& Farren, 2016; Gaden-Hence, 2017).

\section{CONCLUSION}

The three objectives posited for consideration in the current study included the following: (1) reviewing pertinent literature aimed at more than 50 years of kindergarten and Pre-K programs; (2) conducting extensive interviews of five pre-K and Kindergarten educators to discern perspectives of professional educators regarding the role of Pre-K programs in preparing children for educational prowess in later years in school.; and (3) identifying limitations of previous research, exploring current strides in Pre-K education, and positing options for educators and parents for predicting success of children in later grades. Objectives (1) and (2) were completed in the aforementioned sections with interpretive and conclusive discussions. Objective (3) is discussed here in three focused commentaries: (a) the limitations of previous research focused on PreK education; (b) the exploration of current strides in Pre-K education in the United States; and (c) positing options for educators and parents interested in predicting success of children in later grades.

\section{LIMITATIONS}

Limitations of the current research are focused on two major concerns: (1) the use of participants from the same large (over 25,000 students) school district may represent a limited perspective of preschool education and/or may not reveal the affect considerations of smaller school districts and (2) the use of only educators within the study may provide a focused educational viewpoint perhaps unlike the use of parents or taxpayers. 


\section{REFERENCES}

Alexander, K. L., Entiwisle, D. R., and Dauber, S. L. (2008). On the success of failure: A reassessment of the effects of retention in the primary grades, Second edition. Cambridge, U. K.: Cambridge University Press.

Barnett, W. S. (2008). Preschool education and its lasting effects: Research and policy implications. Boulder and Tempe: Education and the Public Interest Center \& Education Policy Research Unit. Retrieved 5/28/2021. http://epicpolicy.org/publication/preschool-education

Center for Public Education (2007). Pre-kindergarten: What the research shows. Alexandria, VA.: National School Boards Association. http://www.centerforpubliceducation.org/mainmenu/pre-kindergarten/pre-kindergarten/pre-Kindergarten-what-the-researchshows.html

Center for Public Education (2008). The research on pre-K. Alexandria, VA.: National School Boards Association. http://www.centerforpubliceducation.org/main-menu/prekindergarten/pre-Kindergarten.

Clements, D. H., Fuson, K. C., and Sarama, J. (2017). The research-based balance in early childhood mathematics: A response to Common Core criticisms. Early childhood research quarterly, 40(3rd quarter), 150-162. https://doi.org/10.1016/j.ecresq2017.03.005

Creswell, J. W. and Clark, V. L. (2018). Designing and conducting mixed methods research, $3^{\text {rd }}$ edition. Thousand Oaks, CA: Sage Publications, Inc.

Cresswell, J. W. and Poth, C. L. (2018). Qualitative inquiry research design, $4^{\text {th }}$ edition. Thousand Oaks, CA: Sage Publications, Inc.

Fitzpatrick, M. D. (2008). Starting school at four: The effect of Universal Pre-Kindergarten on children's academic achievement. The B. E. Journal of Economic Analysis \& Policy, 8 (1), Article 46, 1-38. DOI: https://doi.org/10.2202/1935-1682.1897

Gaden-Hence, F. F. (2016). The relationship between early childhood education and student success. Dissertations 360. http://aquila.usm.edu/dissertations/360

Gormley, W. T. (2017). The universal pre-K bandwagon, Sage Publications. Phi Delta Kappan, 87(3), 246-249. https://doi.org/10.1177/003172170508700319.

Knechtel, V., Thomas, C., Caronongan, P. Fung, N., and Goble, L. (2017). Pre-Kindergarten impact over time: An analysis of KIPP Charter schools. Washington, D. C.: Mathematics Policy Research Report. $\quad$ https://www.mathematica-mpr.com/our-publications-andfindings/publications/pre-kindergarten-impacts-over-time-an-analysis-of-kipp-charterschool.

Learning Policy Institute (2021). Building a national early childhood education system that works. https://learningpolicyinstitute,org/sites/default/files/product-files/LPI Early Childhood2021BRIEF.pdf

Lipsey, M. W. and Farren, D. C. (2016). Effects of a state pre-kindergarten program on children's achievement and behavior through third grade (Working paper). Peabody College: Peabody Research Institute.

https://peabody.vanderbilt.edu/research/pri/TNVPK_Grade_3_working_paper.pdf

Marcon, R. A. (2002). Moving up the grades: Relationship between preschool model and later school success. Early childhood research and practice: An internet journal on the development, care, and education of young children, 4(1), 1-23. http://ecrp.uiuc.edu/v4n1/marcon.htm 
Marshall, C. and Rossman, G. B. (1999). Designing qualitative research, $3^{\text {rd }}$ edition. Thousand Oaks, CA: Sage Publications, Inc., http://psycnet.apa.org/record/1999-02689-000

Pianta, R.C., Barnett, W. S., Burchina, M. and Thornburg, K. R. (2009). The effects of preschool education: What we know, how public policy is or is not aligned with the evidence base, and what we need to know. Psychological science in the public interest, 10(2), 49-88. https://doi.org/10.1177/1529100610381908

Rubin, H. J. and Rubin, I. S. (2005). Qualitative interviewing: The art of hearing data, Second edition. Thousand Oaks, CA: Sage Publishers. http://methods.sagepub.com/book/qualitativeinterviewing

Seiber, J. E. and Tolich, M. B. (2013). Planning ethically responsible research, Second edition. Thousand Oaks, CA: Sage Publishers.

Stevenson, H. W. and Newman, R. S. (1986). Long-term prediction of achievement and attitudes in mathematics and reading. Child development, 57, 646-659. https://www.jstor.or/stable/1130343?seq=1\#page_scan_tab_contents

Warner, R. M. (2013). Applied statistics: From bivariate through multivariate techniques. Thousand Oaks, CA: Sage Publications, Inc. 